\title{
Substitution of sodium chloride by potassium chloride in São João cheese of Pico Island
}

\author{
Catarina Soares ${ }^{1}$ • Ana Luísa Fernando ${ }^{1}$. \\ Nuno Alvarenga ${ }^{2,3,4}$ • António P. L. Martins ${ }^{5,6}$
}

Received: 29 August 2015 / Revised: 11 May 2016 / Accepted: 23 May 2016 /

Published online: 13 June 2016

(C) INRA and Springer-Verlag France 2016

\begin{abstract}
The effect of partial to total substitution of $\mathrm{NaCl}$ with $\mathrm{KCl}$ on the physicochemical, microbiological, textural, and sensory properties of São João cheese, a soft cheese produced in Pico Island, Portugal, was studied. São João cheeses were made with five different curd dry salting treatments $(4 \%, w / w)$, including (A) $\mathrm{NaCl}$ only (control), (B) $3 \mathrm{NaCl} / 1 \mathrm{KCl}$, (C) $1 \mathrm{NaCl} / 1 \mathrm{KCl}$, (D) $1 \mathrm{NaCl} / 3 \mathrm{KCl}$ mixtures, and (E) $\mathrm{KCl}$ only, and then ripened at $11{ }^{\circ} \mathrm{C}$ for 40 days. Sodium replacement by potassium did not influence the protein, fat, and ash contents at the same sampling day, as well as the overall microbiology quality, but acidity decreased significantly. Replacing $\mathrm{NaCl}$ with $\mathrm{KCl}$ reduced significantly the moisture content of cheeses up to 17 days of ripening, along with the expected parallel $\mathrm{Na}$ reduction/K increase contents. The sensory analysis indicated that a reduced-sodium São João cheese could be produced by using $\mathrm{KCl}$ as a partial to total $\mathrm{NaCl}$ replacer. However, the texture profile showed that hardness increased significantly while cohesiveness
\end{abstract}

Catarina Soares

cps13560@ campus.fct.unl.pt

$\triangle \quad$ Ana Luísa Fernando

ala@fct.unl.pt

1 MEtRiCS/Departamento de Ciências e Tecnologia da Biomassa, Faculdade de Ciências e Tecnologia, FCT, Universidade Nova de Lisboa, Campus de Caparica, 2829-516 Caparica, Portugal

2 Instituto Politécnico de Beja, Escola Superior Agrária, Rua Pedro Soares, Apartado 6158, 7801-908 Beja, Portugal

3 GeoBioTec Research Institute, Universidade Nova de Lisboa, Campus de Caparica, 2829-516 Caparica, Portugal

4 LEAF, Instituto Superior de Agronomia, Universidade de Lisboa, Tapada da Ajuda, 1349-017 Lisbon, Portugal

5 UEISTSA, INIAV IP, Quinta do Marquês, Av. da República, 2780-157 Oeiras, Portugal

6 Departamento de Ciências e Engenharia de Biossistemas, Instituto Superior de Agronomia, Universidade de Lisboa, Tapada da Ajuda, 1349-017 Lisbon, Portugal 
decreased significantly with the increasing substituting amount of $\mathrm{KCl}$. Therefore, considering the sensory, physicochemical, and microbiological properties in combination to the textural results, cheeses formulated with $(3: 1)$ or $(1: 1) \mathrm{NaCl} / \mathrm{KCl}$ blends were considered as the most appropriate to be manufactured on an industrial scale. Moreover, the use of (1:1) $\mathrm{NaCl} / \mathrm{KCl}$ mixture reduced the $\mathrm{Na} / \mathrm{K}$ ratio from 6.1 in the control cheese to the desired 1.0.

Keywords São João cheese · Substitution of sodium chloride - Sodium · Potassium • Cheese texture $\cdot$ Cheese composition . Cheese minerals

\section{Introduction}

Sodium intake is known to be essential for human health as it is one of the main electrolyte components of extracellular fluids. It enables the transport of nutrients (Wyatt 1983) and contributes to the regulation of blood pressure, transfer of intracellular water, regulation of osmotic pressure, and transmission of nerve impulses (Cruz et al. 2011). The recommended sodium daily intake is $2.4 \mathrm{~g}$ for healthy adults, which is equivalent to $6 \mathrm{~g} \mathrm{NaCl}$ (Kaplan 2000). However, an excessive dietary sodium intake, mostly in developed countries, is reported (Drake et al. 2011), which is associated with unhealthy effects, such as blood pressure increase with the very likely development of cardiovascular diseases (Cook et al. 2007) or increment of calcium renal excretion, due to lower calcium absorption, which may lead to osteoporosis and to incidence of renal calculi (kidney stones) (Massey 2005). Due to the aforementioned effects, reduction of sodium chloride contents in food is one of the main focuses of attention in the European Union, as it is known that the mean daily salt intake in the European population ranges from 8 to $11 \mathrm{~g}$ salt/day (3-5 g of sodium). The Regulation (EC) No. 1924/2006 on nutrition and health claims made on foods allows "low sodium/salt," "very low sodium/ salt," and "sodium-free or salt-free" labelling for foods containing low salt levels, in agreement with the fixed limit.

Cheese is considered as being a rich source of sodium as its chloride salt content is usually high ranging from $0.7 \%(w / w)$ in Swiss type to approximately $6 \%(w / w)$ in Domiati (Guinee and Fox 2004). Within the dairy industry, sodium chloride is traditionally used as a preservative and as a flavor enhancer. Sodium carries out important functions on cheese, mainly concerning bacterial growth, protein hydration, enzyme activity, and syneresis (Ayyash and Shah 2010; Guinee and Fox 2004; Cruz et al. 2011). When the salt concentration in cheeses is reduced, proteolysis, water activity, acidity, and bitterness increase while firmness decreases and irregular fermentations occur (Ayyash and Shah 2010). Hence, food manufacturers are reluctant to reduce the levels of $\mathrm{NaCl}$ in their products because they are afraid of profit losses due to loss of palatability and safety of their products (Cruz et al. 2011; Kamleh et al. 2012). However, it is reported that a reduction of up to 35-37.5\% in the amount of added $\mathrm{NaCl}$, in acid curd cottage cheese or long cured Cheddar cheese, did not affect significantly their acceptability (Wyatt 1983). Substitution of sodium chloride with other salts is considered an alternative approach to reduce sodium in cheeses. Potassium chloride $(\mathrm{KCl})$ has been recognized as a potential salt replacer (Ayyash and Shah 2010; Cruz et al. 2011; Kamleh et al. 2012). In addition, 
numerous studies have shown that an increased intake of potassium in the diet can decrease the effect of sodium-induced hypertension by lowering the blood pressure and reduce the urinary calcium excretion with subsequent bone mass maintenance and osteoporosis prevention (Cruz et al. 2011; Kamleh et al. 2012).

Several studies have assessed the potential of potassium as a sodium substitute on cheese processing. Demott et al. (1984) found that partial (50\%) substitution of $\mathrm{NaCl}$ with $\mathrm{KCl}$ in Cottage cheese revealed similar acceptability to the fullsodium control. Katsiari et al. $(1997,1998)$ also reported that sodium contents of Feta and Kefalograviera cheeses can be successfully reduced by $50 \%$, when $\mathrm{NaCl}$ is partially replaced with $\mathrm{KCl}$, once gross composition and sensory properties are not affected. Similar findings were observed by Aly (1995) in ultrafiltrated Feta-type cheese, by Kamleh et al. (2012) in Halloumi cheese, and by Lindsay et al. (1982), and Grummer et al. (2012) in Cheddar cheese. However, increasing the substitution of sodium level by more than $50 \%$ results, generally, in a significant decrease in flavor, as it was reported by Demott et al. (1984) in Cottage cheese. Moreover, cheeses salted solely with potassium chloride were extremely bitter and showed alterations in texture (Cruz et al. 2011). Nevertheless, a mitigation of those effects can be reached by combinations of reduced-sodium cheese with emulsifiers, such as potassium salts (citrates and phosphates), and flavor enhancers in the base formulation (Karahadian and Lindsay 1984).

Efforts to reduce the level of sodium in cheeses, either by simple reduction of $\mathrm{NaCl}$ or by partial substitution, addressed mainly Cheddar (long cured and hard), cottage (fresh acid curd), and feta-type (white-brined ripened for at least two months) cheeses. Recently, Soares et al. (2015) reported the feasibility of simply reducing the sodium chloride content up to $25 \%$ on São João cheese of Pico Island. São João cheese, made with pasteurized full fat bovine milk, is a Portuguese popular cheese from Pico Island consumed in the Azores Archipelago. This cheese variety has a salty taste and moderate to intense aroma, and its inner color varies from yellowish to whitish. The level of $\mathrm{NaCl}$ in São João cheese is typically around $2 \%\left(\mathrm{~g} \mathrm{Cl}^{-}\right.$per $100 \mathrm{~g}$ cheese), though it can range from $0.95 \%$ to $2.3 \%$ or more (Despacho Normativo (Legislative Order), No. 32 of 29 October 1996). The moisture in a fat-free basis ranges from $66 \%$ to $84 \%$, while fat-in-dry-matter ranges from $45.0 \%$ to $60.0 \%$ (Despacho Normativo (Legislative Order), No. 32 of 29 October 1996). Therefore, this cheese is characterized by a very soft to semisoft body and pasty texture developed throughout a short to medium period of ripening time (usually 17 days). As information is lacking on soft ripened cheese varieties using $\mathrm{KCl}$ as a salt replacement of sodium chloride, this work aimed at studying the effect of replacement of $\mathrm{NaCl}$ with $\mathrm{KCl}$ on the quality of São João cheese. In this study, the physicochemical, textural, and sensory characteristics, as well as the microbiological quality of substitutedsodium São João cheeses, were determined in comparison with those of the full-sodium control. It must be highlighted that no information is available concerning the effect of salt substitution on the quality of any traditional or other type of Portuguese cheese. 


\section{Materials and methods}

\subsection{Cheesemaking}

The São João cheese was produced on two different days, according to the conventional procedure of the manufacturer, in a local dairy plant on Pico Island pertaining to São João, a civil parish in the municipality of Lajes do Pico. In brief, full fat bovine milk (1000 L), presenting a protein content of $3.4 \%$ and a fat content of $4.0 \%$, was pasteurized at $74.5^{\circ} \mathrm{C}$ for $15 \mathrm{~s}$ using plate pasteurizer (Frinox SA, La Coruña, Spain). Milk was tempered to $29^{\circ} \mathrm{C}$ and commercial starter culture consisting of Lactococcus lactis ssp. lactis and L. lactis ssp. cremoris was added (Lyofast MO 030, 10 unit sachet/ $1000 \mathrm{~L}^{-1}$ milk; Caglificio Clerici, Como, MI, Italy). Then, $200 \mathrm{~mL}$ of liquid calcium chloride solution $\left(\mathrm{CaCl}_{2}, 20 \% \mathrm{w} / \mathrm{v}\right.$, Caglificio Clerici) were also added to $1000 \mathrm{~L}$ of milk. The milk was allowed to ripen for $20 \mathrm{~min}$ in a closed vat. The total volume of cheesemilk was then split into two opened rectangular vats of $500 \mathrm{~L}$ capacity (BPL SA, Lisboa, Portugal), and $75 \mathrm{~mL}$ of liquid rennet consisting of $92 \%$ chymosin and $8 \%$ pepsin (165 IMCU.mL ${ }^{-1}$, Caglificio Clerici), diluted in $750 \mathrm{~mL}$ of cold water, was added in each $500 \mathrm{~L}$ vat and mixed well for $1 \mathrm{~min}$. The milk's $\mathrm{pH}$ was 6.8 prior to addition of starters and 6.6 after the addition of starters, before rennet's addition (in the vat). The coagulation was achieved in about $30 \mathrm{~min}$ at $29-30{ }^{\circ} \mathrm{C}$. The curd was cut manually and rest for $15 \mathrm{~min}$, before stirring. After whey draining, the milled curd was sub-divided into five batches and the curd-milled pieces were mixed directly with dry salt crystals $\mathrm{NaCl}$ or with food-grade $\mathrm{KCl}$ either single or as $\mathrm{NaCl}$ and $\mathrm{KCl}$ mixtures as follows: $4 \mathrm{~g} \mathrm{NaCl} / 100 \mathrm{~g}$ (control, cheese A), $3 \mathrm{~g} \mathrm{NaCl} / 100 \mathrm{~g}+1 \mathrm{~g} \mathrm{KCl} / 100 \mathrm{~g}(3 \mathrm{NaCl} /$ $1 \mathrm{KCl}$, cheese B), $2 \mathrm{~g} \mathrm{NaCl} / 100 \mathrm{~g}+2 \mathrm{~g} \mathrm{KCl} / 100 \mathrm{~g}(1 \mathrm{NaCl} / 1 \mathrm{KCl}$, cheese C), $1 \mathrm{~g}$ $\mathrm{NaCl} / 100 \mathrm{~g}+3 \mathrm{~g} \mathrm{KCl} / 100 \mathrm{~g}(1 \mathrm{NaCl} / 3 \mathrm{KCl}$, cheese D), and $4 \mathrm{~g} \mathrm{KCl} / 100 \mathrm{~g}(\mathrm{KCl}$ only, cheese E) (Fig. 1). The mass of added salt to each batch was calculated based on the manufacturer procedure for the control cheese $(2 \mathrm{~kg} \mathrm{NaCl}$ per $500 \mathrm{~L}$ of pasteurized milk) and on the weight of milk and previous knowledge on the São João cheese yielding capacity (10\%). After curd dry salting, cheeses were molded and pressed in a hydraulic horizontal press (mod. PP08086, Arsopi SA, Vale de Cambra, Portugal) to drain further. Eight replicates of each salt formulation, weighing ca. $0.85 \mathrm{~kg}$ each, were produced (Fig. 1). The molds were inverted only once during $1 \mathrm{~h}$ of pressing. In order to prevent microbiological spoiling, natamycin (Caglificio Clerici) was applied onto the surface of the cheese by dipping it into an aqueous suspension. Cheeses were placed in ripening rooms at $9-11^{\circ} \mathrm{C}$ and $80-83 \%$ of relative humidity for 40 days and overturned every day during the first week and then every 2 days.

Physicochemical analyses were carried out at each sampling point whereas microbiological, textural, and sensory analyses at 17 days of ripening, which is the minimum ripening time required for this cheese variety. Microbiological, textural, and sensory analyses were performed promptly upon receipt of the cheeses in the laboratory. The samples for physicochemical analysis were stored at $-20{ }^{\circ} \mathrm{C}$ until analysis. The results

Fig. 1 Flow diagram of São João cheese manufacture, being $A=\mathrm{NaCl}$ only (control), $B=3 \mathrm{NaCl} / 1 \mathrm{KCl}(w / w)$, $C=1 \mathrm{NaCl} / 1 \mathrm{KCl}(w / w), D=1 \mathrm{NaCl} / 3 \mathrm{KCl}(w / w)$, and $E=\mathrm{KCl}$ only. This procedure was repeated twice, on two different occasions, in order to achieve two trials of São João cheese, hence providing four replicates for each salting treatment 
Pasteurized cheesemilk, $500 \mathrm{~L}$

inoculated with the starter (Lyofast MO 030, 10 Unit sachet $1000 \mathrm{~L}^{-1}$ ) and with the addition of $\mathrm{CaCl}_{2}$ at a $40 \mathrm{~g} \cdot 1000 \mathrm{~L}^{-1}$ rate
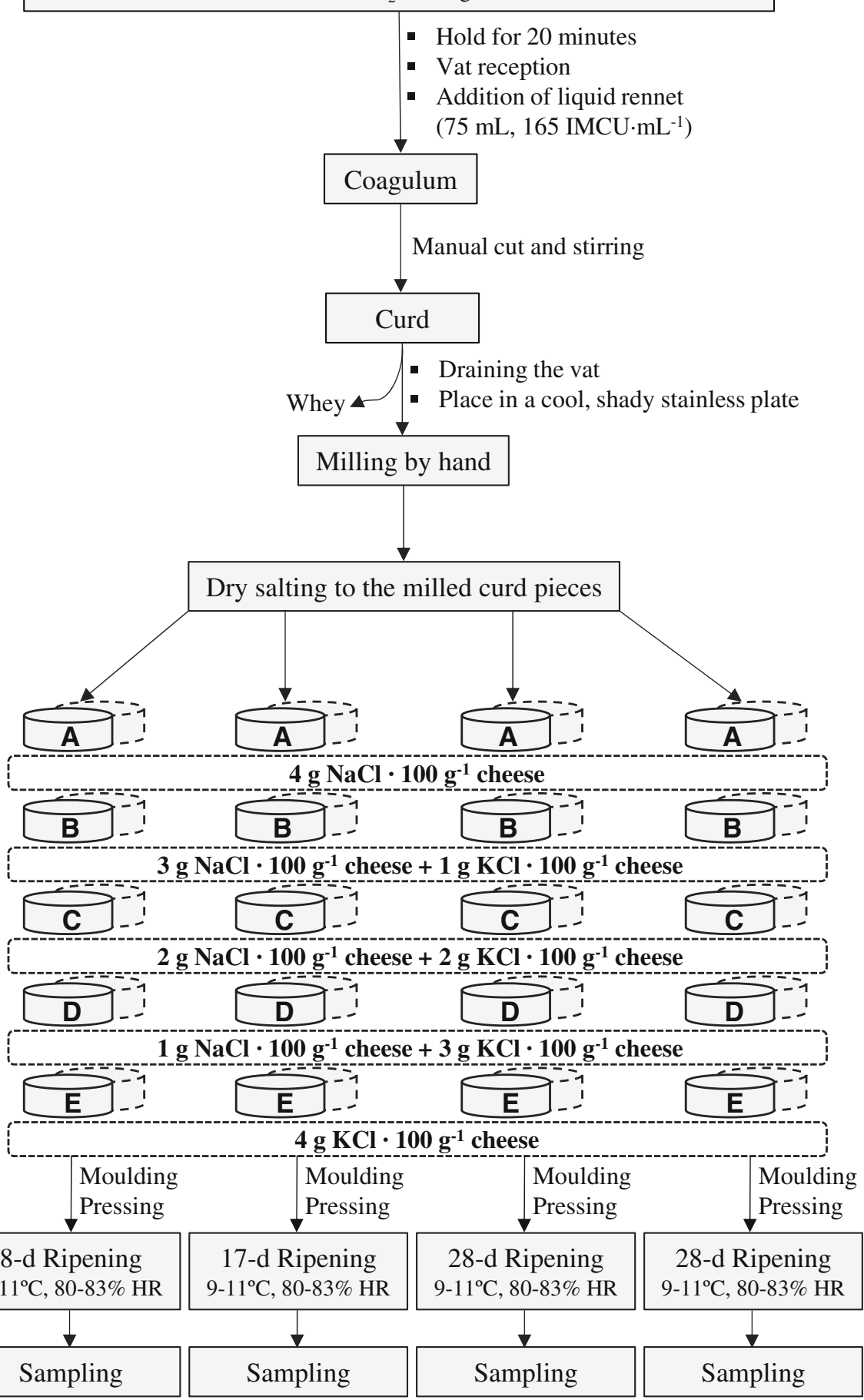
were expressed as mean values \pm standard deviation (SD) of the four replicates.

\subsection{Physicochemical analysis}

About a quarter of each experimental cheese was taken and further cut into radial slices according to IDF (2008a), which were grated after the removal of rind. Moisture was determined by oven-drying method at $103 \pm 2{ }^{\circ} \mathrm{C}$ following standard method 948.12 (AOAC 1990). Fat and ash were determined by acid extraction and muffle furnace method described by standard methods 933.05 and 905.02 in AOAC (1990) and 935.42 in AOAC (1990), respectively. Cheese acidity was determined by titrimetric method 920.124 (AOAC 1990). Total protein (total nitrogen $\times 6.38$ ) was determined using a Kjeltec System, consisted of the Digestion System Tecator 2006 and the Distilling Unit 1002 (Tecator, Höganäs, Sweden), based on Kjeldahl method described in IDF (2008b). Chloride content was determined according to IDF (2006) - to extract chlorides from cheese - combined with Mohr's method for quantification of chloride ion concentration by precipitation titration with silver nitrate. Lactose in the cheese samples was determined following the method of Munson and Walker for the gravimetric determination of the total reducing sugars by the alkaline copper tartrate reagent described in NP (1998) protocol. The $\mathrm{pH}$ of grated cheese $(5 \mathrm{~g})$ homogenized in $50 \mathrm{~mL}$ of deionized water was measured with a $\mathrm{pH}$ glass electrode attached to a calibrated Crison MicropH 2001 potentiometer (Crison Instruments, Barcelona, Spain).

The total phosphorous content was determined by molecular absorption spectrometric method as described in IDF (2010). Samples for mineral analysis were dried overnight at $103 \pm 2{ }^{\circ} \mathrm{C}$ and incinerated at $550{ }^{\circ} \mathrm{C}$ for $6 \mathrm{~h}$. The ash digested with nitric acid was analyzed for macroelements. Sodium, potassium, calcium, and magnesium contents were measured by atomic absorption spectrometry (Solaar M Series, Thermo Scientific, Cambridge, UK) according to IDF (2007); calibration samples were prepared from single element certified standard solutions (Merck, Darmstadt, Germany) with concentration of 1 g. $\mathrm{L}^{-1}$, and all reagents were of analytical reagent grade.

\subsection{Microbiological analysis}

The microbiological quality of the cheese samples was examined by determining the total bacterial count, Enterobacteriaceae, coagulase positive staphylococci, and yeasts and molds at 17 days of ripening. For this purpose, cheese samples (100 g) were collected aseptically into sterile sample bags. The initial suspension and further decimal dilutions were prepared in $0.1 \%(w / v)$ sterile peptone water (Oxoid, Unipath Ltd., Basingstoke, UK) as described in ISO 6887-1 (1999). Total mesophilic bacteria counts were performed on standard plate count agar (PCA) (Becton, Dickinson and Company, Franklin Lakes, NJ, USA), after incubation at $30{ }^{\circ} \mathrm{C}$ for $72 \mathrm{~h}$. Enterobacteriaceae were enumerated on violet red bile glucose agar (VRBGA) (Biokar Diagnostics, Beauvais, France) and coagulase positive staphylococci on Baird-Parker medium supplemented with egg yolk tellurite agar (Himedia, Mumbai, India), being both incubated aerobically at $37^{\circ} \mathrm{C}$ for $24 \mathrm{~h}$ (former agar medium) or 44 to $48 \mathrm{~h}$ (later agar medium). Rose Bengal Chloramphenicol (RBC) Agar (Biokar Diagnostics) was used to count yeasts and molds after incubation in aerobic conditions at $25^{\circ} \mathrm{C}$ for $120 \mathrm{~h}$. Counts were expressed as $\log _{10}$ of colony forming units per gram of sample. Determination of Escherichia coli 
was carried out by following the main steps described in ISO (2005). The detection of Salmonella spp. and Listeria monocytogenes was performed according to horizontal method described at ISO (2002) and ISO (1998), respectively.

\subsection{Sensory evaluation}

Triangle test was performed at 17 days of ripening of the second trial in order to detect any difference regarding the salting treatment applied in São João cheese making. The test aimed at identifying which sample out of three was different in regard with one or a set of sensory properties. The group of assessors consisted of 30 untrained judges (18 females and 12 males, in which the age average stood between 18 and 30 years over an age range of 18 to more than 51 years old) who were selected based on their willingness to participate and time availability. They were mostly degree, master's, and $\mathrm{PhD}$ students but also scholarship holders, professors, and staff of Faculty of Sciences and Technology of New University of Lisbon. Judges were not informed about the details of the project. They were not familiarized with São João cheese and its characteristics; therefore, a brief explanation of the product was given prior to sample assessment. Different commercial standards (control cheeses and others directly acquired from the São João Dairy, all with the same ripening period of the experimental cheeses) and experimental samples were provided during each session. The triangle test was performed as follows: samples were combined in a set of three of six possible groups of two different cheeses, where two were similar and one was different. Thirty tests for each salt treatment were performed in total as described in BS (2004). Two sensory sessions were carried out in the morning and in the afternoon of each testing day, at least $1 \mathrm{~h}$ after the subjects' last meal. The samples were presented in $1.5-\mathrm{cm}^{3}$ cubes. The pieces were held at ambient temperature $\left(18 \pm 2{ }^{\circ} \mathrm{C}\right)$ in white plastic plates, aligned from left to right, and labelled with three-digit unique random numbers. Subjects were instructed to assess organoleptically the samples in the order that has been given. Water was provided along with the samples for mouth washing between samples. Finally, they were asked to indicate in the score sheet which one of the three samples was different from the other two. Importance was predominantly given to flavor, texture, and odor attributes over cheese appearance. At the end of the score sheet, there was a comment section for the assessor's remarks on any flavor, texture, or odor defects. Thereafter, the number of correct responses was ascertained and, then, the accounted number for each salting treatment was checked to be greater or equal to the minimum number of correct responses displayed on the statistical table of BS (2004), at 5\% significance level. If so, a perceptible difference between control and experimental cheeses was drawn.

\subsection{Texture profile analysis}

Instrumental texture profile analyses (TPA) was performed on a TAHD $i$ texture analyzer (Stable Micro Systems, Godalming, UK) according to Alvarenga et al. (2008, 2011) with some modifications. Cheeses from the second trial on 17th day of ripening were equilibrated at room temperature $\left(20 \pm 1^{\circ} \mathrm{C}\right)$ during $12 \mathrm{~h}$. The consumers generally held the São João cheese in the refrigerator, but they eat the cheese at room temperature. The diameter of cheeses ranged from 16 to $17 \mathrm{~cm}$ and its height was $3 \mathrm{~cm}$. 
Cheese samples were punctured to $10 \mathrm{~mm}$ of penetration depth using a 50-N load cell with a 20-mm-diameter aluminum cylindrical probe with a crosshead speed adjusted to $1.0 \mathrm{~mm} . \mathrm{s}^{-1}$ and the time elapsed between the first and second bite was $5 \mathrm{~s}$. In each cheese sample, $0.5 \mathrm{~cm}$ layer of the upper surface was removed in order to expose a homogeneous surface of the inside, allowing texture determinations. At least five replicate measurements were carried out for each cheese. From the force vs. time texturograms, two parameters were obtained: hardness and adhesiveness. Hardness (N) is defined as the maximum force and adhesiveness (-N.mm) the negative surface of the graph force vs. distance. The ratio between the work performed in the second cycle by the work of the first cycle provides the dimensionless parameter cohesiveness.

\subsection{Statistical analysis}

The results from physicochemical composition and mineral contents were assessed by analysis of variance, either one-way or two-way ANOVA, depending on the analysis scheme, to ascertain significant differences among the salting treatments applied in cheese manufacture, as well as during ripening. Each main effect was tested as well as their interactions. Whenever significant $(p<0.05)$ differences were found among salting treatments, the Student's $T$ test was used to make pairwise comparisons of their mean values. Significance was established at $p<0.05$. The statistical analysis was performed using the software Analysis ToolPack for Windows (a Microsoft Excel add-in program, 2010, Microsoft Corporation, Redmont, WA, USA). Differences that resulted from one-way ANOVA were tested by Fisher's test.

\section{Results and discussion}

\subsection{Physicochemical characterization}

The effect of substitution of $\mathrm{NaCl}$ by $\mathrm{KCl}$ on the compositional and the physicochemical evolution of São João cheese throughout ripening is presented in Table 1. In terms of gross composition, the ANOVA results showed that all variables (Table 1) changed significantly $(p<0.05)$ throughout ripening, with the exception of protein. In general, moisture and moisture in the non-fat substance (MNFS) decreased, while ash, salt, saltin-moisture $(\mathrm{S} / \mathrm{M})$, and fat contents increased during ripening at the same salt treatment due to moisture loss through the rind (Aly 1995).

In our study, there were no significant differences $(p>0.05)$ in protein, fat, and moisture content among the full-sodium control and reduced-sodium experimental cheeses at the same sampling date. These findings are in agreement with those of Katsiari et al. (1997, 1998), Aly (1995), and Ayyash and Shah (2010) on the effect of partial substitution of $\mathrm{NaCl}$ by $\mathrm{KCl}$ in Feta, Kefalograviera, UF Feta-type, and Halloumi cheeses, respectively. However, it was possible to verify that the moisture parameter of $\mathrm{NaCl} / \mathrm{KCl}$ and $\mathrm{KCl}$-salted cheeses revealed a general upward trend with the increasing addition of $\mathrm{KCl}$ at all sampling days. A reasonable thought would be that the effect observed in the present study is most likely due to the higher water-holding capacity by the protein matrix inherent to these particular $\mathrm{NaCl} / \mathrm{KCl}$ and $\mathrm{KCl}$-salted cheeses (Guinee and Fox 2004; Grummer 


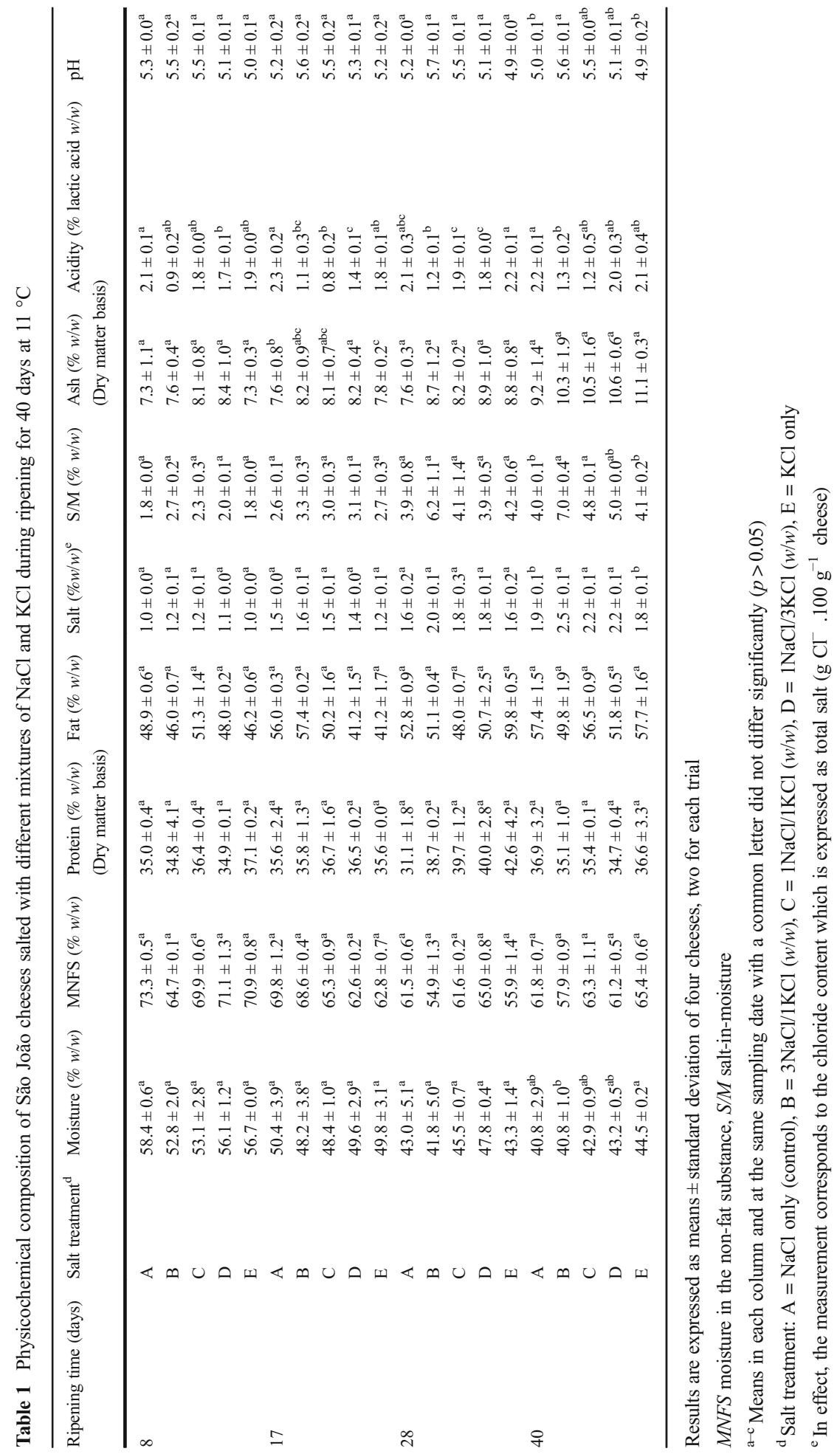


et al. 2012) as these cheeses revealed inner pores in their matrix containing free water within them. Accordingly, it was observed by visual inspection that experimental cheeses exhibited small inner voids containing free water (whey pockets), which were distributed throughout the whole cheese matrix (Guinee and Fox 2004). Besides, the higher the $\mathrm{KCl}$ addition the higher the number of whey pockets in the cheese matrix. Owing to this physical effect, the cheeses with higher percentages of potassium chloride, such as $75 \%$ and $100 \% \mathrm{KCl}$, revealed to be more swollen, presenting, therefore, a spongy texture. However, it can also be seen from Table 1 that all cheeses had similar $(p>0.05)$ MNFS values, in agreement with Katsiari et al. $(1997,1998)$ on Feta and Kefalograviera cheeses, respectively. Yet, according to the MNFS values and the Codex General Standard for Cheese (Codex 1978), at 17 days of ripening, experimental cheeses A and B can be designed as soft cheeses (MNFS $>67 \%$ ), but experimental cheeses C, D, and $\mathrm{E}$ should be designed as semi-hard (MNFS in the range 54-69\%). At 28 and 40 days of ripening, all the cheeses should be designed as semi-hard.

On the other hand, there were no significant $(p>0.05)$ differences in protein among experimental cheeses and that to the control, similar to Ayyash and Shah (2010) and Katsiari et al. (1997, 1998) for Halloumi, Feta, and Kefalograviera cheeses, respectively, made with mixtures of $\mathrm{NaCl} / \mathrm{KCl}$. Nevertheless, a slight $(p>0.05)$ protein increase was generally found with the incremental addition of $\mathrm{KCl}$ in São João cheese at each point throughout ripening except for 40 days. This effect may be attributed to a more compact texture that results from the proteolysis biochemical event (Ayyash et al. 2011). Moreover, it was found that there was a slight dip in the protein content of the $(1: 3) \mathrm{NaCl} / \mathrm{KCl}$-salted cheese at 8 and 40 days of ripening, probably because of a higher resistance to a certain degree in the outflow of whey in this particular cheese (Grummer et al. 2012). In general, this finding is similar to that obtained in a previous work by Soares et al. (2015), who reported a significant protein increase with sodium reduction at each sampling date throughout ripening. The effect observed by these authors was most likely due to an excessive dehydration of protein cheese matrix as a result from very low salt concentrations applied to the experimental cheeses.

Fat contents met the legal specifications of the registered PDO "Queijo do Pico" $(45 \%$ to $60 \%, w / w)$, a similar cheese from the same Island, and did not differ among salt treatments at each point throughout ripening, corroborating the findings of Katsiari et al. (1997, 1998) and Ayyash and Shah (2010) for Feta, Kefalograviera, and Halloumi cheeses, respectively, made with $\mathrm{NaCl} / \mathrm{KCl}$ blends. There was, however, a significant overall fat increase during the entire ripening process, probably associated to moisture decrease with time due to the exudation of a progressive minor amount of cheese serum (Aly 1995).

It was found that there was a significant $(p<0.05)$ overall rise in both salt and mineral contents over the entire ripening period, due to moisture loss (Aly 1995). In the present study, the incremental addition of $\mathrm{KCl}$ caused a respective ash increase at the same sampling date, mainly up to $75 \%$ salt replacement, which was not statistically significant. There were some fluctuations in salt among experimental cheeses, not significant, due to the manufacturing processing, which is manual and therefore not the most efficient to obtain an uniform product. Nevertheless, the curd dry salting method applied in the production of São João cheese enables a more homogeneous salt 
distribution from the beginning of the manufacturing process (Cichoscki et al. 2002), despite the manual handling.

The $\mathrm{S} / \mathrm{M}$ values are important once they are considered necessary for proper ripening fermentations (Katsiari et al. 1997). As one can see in Table 1, the S/M values were not significantly affected by the type of salt used, with the only exception of 40 days of ripening, when the experimental cheeses salted with mixtures $\mathrm{NaCl} / \mathrm{KCl}$ showed higher $(p<0.05)$ values than the control and the $\mathrm{KCl}$-salted São João cheese.

Lactose content of São João cheese was completely metabolized after 8 days of ripening due to glycolysis of residual lactose to lactate, by starters. A significant $(p<0.05)$ increase of titratable acidity during cheese ripening with the sharpest lying between the 17th and 28th day was observed similarly to the report of Soares et al. (2015) on the effect of simply lowering sodium on São João cheese. The same was also found by Ayyash and Shah (2010) who reported that lactic acid increased significantly during storage of Halloumi cheese kept in brine at $4{ }^{\circ} \mathrm{C}$ (although this is a different cheese variety). Conversely, there was a very slight overall $\mathrm{pH}$ reduction over ripening, although no statistical difference was found similarly to Soares et al. (2015). This biochemical event is mainly related to the starter culture added prior to coagulation (Cichoscki et al. 2002), where lactic acid is produced from lactose metabolism by lactic acid bacteria (Ayyash and Shah 2010). Cheeses salted with mixtures of $\mathrm{NaCl} / \mathrm{KCl}$ up to $75 \%$ replacement of $\mathrm{NaCl}$ by $\mathrm{KCl}$ presented significantly $(p<0.05)$ lower acidity than the control, corroborating the findings of Aly (1995) in his study on the effect partial substitution of $\mathrm{NaCl}$ by $\mathrm{KCl}$ for UF Feta-type cheese. As one can see and regardless the control São João cheese, there is an increasing trend with the incremental degree of $\mathrm{NaCl}$ replacement among the reduced-sodium experimental cheeses, similar to McMahon et al. (2014) who found an increase in lactic acid content with the increasing addition of $\mathrm{KCl}$ in Cheddar cheeses. Accordingly, the corresponding data for $\mathrm{pH}$ values were generally slightly $(p>0.05)$ higher in the $\mathrm{NaCl} / \mathrm{KCl}$-salted experimental São João cheeses up to $50 \%$ replacement than those of control at almost all sampling dates throughout ripening as expected. These findings are in agreement with those of Lindsay et al. (1982), Aly (1995), and Ayyash and Shah (2010) on the effect of partial substitution of $\mathrm{NaCl}$ by $\mathrm{KCl}$ for Cheddar, UF Feta-type, and Halloumi cheeses, respectively. It is suggested that the salt replacer $(\mathrm{KCl})$, when used in blends with $\mathrm{NaCl}$, can inhibit the utilization of lactose for acid production by the starter culture more than $\mathrm{NaCl}$ or $\mathrm{KCl}$ alone (Grummer et al. 2012). On the other hand, there is a general decreasing trend in $\mathrm{pH}(p>0.05)$ with the increase of $\mathrm{KCl}$ in experimental São João cheeses at same sampling date, remaining that tendency at each point throughout ripening, similar to McMahon et al. (2014) for full-fat Cheddar cheese, who reported a decreasing trend in $\mathrm{pH}$ with $\mathrm{NaCl}$ substitution by $\mathrm{KCl}$. Lastly, it was found in this study that São João cheese salted with $\mathrm{KCl}$ alone revealed the lowest $\mathrm{pH}$ values $(p>0.05)$, which, in turn, might suggest an empowering effect of $\mathrm{K}^{+}$toward the enzymatic activity of lactic acid bacteria (Grummer et al. 2012).

\subsection{Mineral content}

Mineral data for São João experimental cheeses are given in Table 2. Despite some fluctuations perceived in phosphorous content during ripening, there was no significant $(p>0.05)$ change on the concentration of this element over the ripening process, in 
accordance to protein content, to which a great amount of cheese phosphorous is bound, namely to the casein micelle by ionic linkage to paracasein molecule in the form of phosphate ion (Cruz et al. 2011). It was found that experimental cheeses salted partially or entirely with $\mathrm{KCl}$ exhibited in general higher phosphorous contents than control; however, the differences were significant $(p<0.05)$ at 17 days of ripening. A possible explanation could be that the likely $\mathrm{Na}^{+}$or $\mathrm{K}^{+}$ion exchange with $\mathrm{Ca}^{2+}$ linked to phosphate ion, attached to paracasein molecule (Ayyash et al. 2011), indicates that potassium can be as effective as is $\mathrm{NaCl}$, in terms of technology, but only when blended with $\mathrm{NaCl}$ in the salting step. Secondly, it was noticed that São João cheese E salted with $\mathrm{KCl}$ revealed, somehow, a higher weakness in the $\mathrm{K}^{+}$-phosphate ionic bond because the cheese fully salted with $\mathrm{KCl}$ showed a higher $\mathrm{P}$ content compared to the control and generally substantially higher phosphorous content than those of the remaining $\mathrm{NaCl} / \mathrm{KCl}$-salted cheeses, at 17 and 28 days of ripening. As Cruz et al. (2011) and Guinee and Fox (2004) reported, this effect may be attributed to the increase of the stereochemical effect caused by the electron cloud of potassium ion, which is considerably farther from the nucleus than sodium ion due to the higher atomic mass of the former resulting in a more stable $\mathrm{Na}^{+}$-phosphate linkage than the $\mathrm{K}^{+}$-phosphate ionic bond.

In the present study, the overall calcium content decreased significantly $(p<0.05)$ during ripening due to the incremental gain of acidity with production of lactic acid by the lactic starters (Ayyash and Shah 2010) and to moisture decrease. The calcium content of all cheeses was similar $(p>0.05)$, in accordance with Lindsay et al. (1982) and Katsiari et al. (1997, 1998), for Cheddar, Feta, and Kefalograviera cheeses, respectively. Nevertheless, most of reduced-sodium experimental cheeses had slightly higher $(p>0.05)$ Ca contents at each point throughout ripening, probably because of the less Ca displacement (Rulikowska et al. 2013) with the increasing added amounts of $\mathrm{KCl}$, probably because of likely difficulties in the ion exchange of $\mathrm{K}^{+}$with $\mathrm{Ca}^{2+}$ for the formation of $\mathrm{K}^{+}$-phosphate ionic linkage, once potassium ion has a higher atomic mass than sodium ion.

As for magnesium, potassium, and sodium contents, there was a significant $(p<0.05)$ overall increase of these elements over ripening due to the dehydration process with time (Aly 1995; Guinee and Fox 2004). As seen in Table 2, there were no significant differences $(p>0.05)$ in $\mathrm{Mg}$ contents among all experimental cheeses. However, sodium concentrations decreased significantly $(p<0.05)$, whereas potassium contents increased significantly $(p<0.05)$ among salting treatments at each sampling date, as expected.

The nutritionally related calculations for $\mathrm{Na}$ and $\mathrm{K}$ of experimental cheeses are presented in Fig. $2 \mathrm{a}$, b. There was a significant $(p<0.05)$ overall increase in the ratio of $\mathrm{Na}$ to $\mathrm{K}$ up to $75 \%$ salt reduction during the entire ripening period due to dehydration process with time (Aly 1995). As expected, $\mathrm{Na} / \mathrm{K}$ ratio decreased significantly $(p<0.05)$ with the gradual substitution of $\mathrm{NaCl}$ by $\mathrm{KCl}$ at the same sampling day. The nutritional recommended $\mathrm{Na} / \mathrm{K}$ ratio is 0.6 for adults on a gravimetric basis or 1.0 on a molecular basis (Reps et al. 2009). The $\mathrm{Na} / \mathrm{K}$ ratio of cheese $\mathrm{C}$ with $\mathrm{NaCl} / \mathrm{KCl}(1: 1)$ was 1.0 , on a molecular basis, while the amount of sodium per a hundred grams was much lower compared to the control cheese, in agreement with Lindsay et al. (1982) for Cheddar cheese. Excluding the São João cheese E salted with $\mathrm{KCl}$, none of the experimental cheeses can be 
Table 2 Evolution of the main mineral contents (dry matter basis) of São João cheeses salted with different mixtures of $\mathrm{NaCl}$ and $\mathrm{KCl}$ during ripening for 40 days at $11^{\circ} \mathrm{C}$

\begin{tabular}{|c|c|c|c|c|c|c|}
\hline $\begin{array}{l}\text { Ripening time } \\
\text { (days) }\end{array}$ & $\begin{array}{l}\text { Salt } \\
\text { treatment }^{\mathrm{d}}\end{array}$ & $\begin{array}{l}\text { P } \\
\left(\text { g. } 100 \mathrm{~g}^{-1}\right)\end{array}$ & $\begin{array}{l}\text { Ca } \\
\left(\text { g. } 100 \mathrm{~g}^{-1}\right)\end{array}$ & $\begin{array}{l}\mathrm{Mg} \\
\left(\mathrm{g} .100 \mathrm{~g}^{-1}\right)\end{array}$ & $\begin{array}{l}\mathrm{Na} \\
\left(\mathrm{g} .100 \mathrm{~g}^{-1}\right)\end{array}$ & $\begin{array}{l}\mathrm{K} \\
\left(\mathrm{g} .100 \mathrm{~g}^{-1}\right)\end{array}$ \\
\hline \multirow[t]{5}{*}{8} & A & $0.83 \pm 0.13^{\mathrm{a}}$ & $1.05 \pm 0.27^{\mathrm{a}}$ & $0.06 \pm 0.01^{\mathrm{a}}$ & $0.83 \pm 0.21^{\mathrm{a}}$ & $0.34 \pm 0.09^{b}$ \\
\hline & B & $0.73 \pm 0.07^{\mathrm{a}}$ & $1.31 \pm 0.26^{\mathrm{a}}$ & $0.05 \pm 0.00^{\mathrm{a}}$ & $0.77 \pm 0.31^{\mathrm{a}}$ & $0.71 \pm 0.06^{\mathrm{c}}$ \\
\hline & $\mathrm{C}$ & $0.87 \pm 0.01^{\mathrm{a}}$ & $0.95 \pm 0.22^{\mathrm{a}}$ & $0.05 \pm 0.10^{\mathrm{a}}$ & $0.50 \pm 0.12^{\mathrm{ab}}$ & $1.03 \pm 0.22^{\mathrm{a}}$ \\
\hline & $\mathrm{D}$ & $0.86 \pm 0.01^{\mathrm{a}}$ & $1.38 \pm 0.86^{\mathrm{a}}$ & $0.04 \pm 0.02^{\mathrm{a}}$ & $0.33 \pm 0.10^{\mathrm{b}}$ & $1.61 \pm 0.09^{\mathrm{a}}$ \\
\hline & E & $0.81 \pm 0.00^{\mathrm{a}}$ & $1.16 \pm 0.21^{\mathrm{a}}$ & $0.06 \pm 0.00^{\mathrm{a}}$ & $0.10 \pm 0.01^{\mathrm{ab}}$ & $1.66 \pm 0.17^{\mathrm{ac}}$ \\
\hline \multirow[t]{5}{*}{17} & A & $0.69 \pm 0.13^{\mathrm{ab}}$ & $0.94 \pm 0.16^{\mathrm{a}}$ & $0.06 \pm 0.01^{\mathrm{a}}$ & $1.20 \pm 0.12^{\mathrm{a}}$ & $0.34 \pm 0.03^{\mathrm{b}}$ \\
\hline & B & $0.67 \pm 0.01^{\mathrm{b}}$ & $0.89 \pm 0.17^{\mathrm{a}}$ & $0.06 \pm 0.00^{\mathrm{a}}$ & $0.91 \pm 0.34^{\mathrm{a}}$ & $0.76 \pm 0.08^{\mathrm{ab}}$ \\
\hline & $\mathrm{C}$ & $0.84 \pm 0.02^{\mathrm{b}}$ & $0.84 \pm 0.25^{\mathrm{a}}$ & $0.06 \pm 0.00^{\mathrm{a}}$ & $0.66 \pm 0.21^{\mathrm{b}}$ & $1.10 \pm 0.14^{\mathrm{a}}$ \\
\hline & $\mathrm{D}$ & $0.85 \pm 0.07^{\mathrm{ab}}$ & $1.04 \pm 0.25^{\mathrm{a}}$ & $0.06 \pm 0.00^{\mathrm{a}}$ & $0.43 \pm 0.12^{\mathrm{bc}}$ & $1.37 \pm 0.23^{\mathrm{a}}$ \\
\hline & E & $0.99 \pm 0.02^{\mathrm{a}}$ & $1.08 \pm 0.23^{\mathrm{a}}$ & $0.05 \pm 0.00^{\mathrm{a}}$ & $0.22 \pm 0.14^{\mathrm{c}}$ & $1.48 \pm 0.13^{\mathrm{a}}$ \\
\hline \multirow[t]{5}{*}{28} & A & $0.67 \pm 0.04^{\mathrm{a}}$ & $0.83 \pm 0.39^{\mathrm{a}}$ & $0.06 \pm 0.01^{\mathrm{a}}$ & $1.33 \pm 0.16^{\mathrm{a}}$ & $0.30 \pm 0.04^{\mathrm{b}}$ \\
\hline & B & $0.83 \pm 0.04^{\mathrm{a}}$ & $0.82 \pm 0.24^{\mathrm{a}}$ & $0.06 \pm 0.00^{\mathrm{a}}$ & $1.11 \pm 0.08^{\mathrm{a}}$ & $0.78 \pm 0.11^{\mathrm{c}}$ \\
\hline & $\mathrm{C}$ & $0.90 \pm 0.01^{\mathrm{a}}$ & $0.76 \pm 0.19^{\mathrm{a}}$ & $0.06 \pm 0.01^{\mathrm{a}}$ & $0.81 \pm 0.03^{\mathrm{a}}$ & $1.05 \pm 0.10^{\mathrm{a}}$ \\
\hline & $\mathrm{D}$ & $0.77 \pm 0.04^{\mathrm{a}}$ & $0.95 \pm 0.28^{\mathrm{a}}$ & $0.06 \pm 0.00^{\mathrm{a}}$ & $0.54 \pm 0.08^{\mathrm{a}}$ & $1.45 \pm 0.02^{\mathrm{a}}$ \\
\hline & $\mathrm{E}$ & $0.90 \pm 0.13^{\mathrm{a}}$ & $1.00 \pm 0.02^{\mathrm{a}}$ & $0.07 \pm 0.00^{\mathrm{a}}$ & $0.13 \pm 0.01^{\mathrm{a}}$ & $1.54 \pm 0.13^{\mathrm{a}}$ \\
\hline \multirow[t]{5}{*}{40} & A & $0.85 \pm 0.01^{\mathrm{a}}$ & $0.76 \pm 0.17^{\mathrm{a}}$ & $0.08 \pm 0.01^{\mathrm{a}}$ & $1.50 \pm 0.11^{\mathrm{a}}$ & $0.41 \pm 0.07^{\mathrm{b}}$ \\
\hline & $\mathrm{B}$ & $0.74 \pm 0.04^{\mathrm{ab}}$ & $0.99 \pm 0.23^{\mathrm{a}}$ & $0.05 \pm 0.01^{\mathrm{a}}$ & $1.30 \pm 0.10^{\mathrm{abc}}$ & $0.78 \pm 0.10^{\mathrm{b}}$ \\
\hline & $\mathrm{C}$ & $0.70 \pm 0.02^{\mathrm{b}}$ & $0.85 \pm 0.20^{\mathrm{a}}$ & $0.06 \pm 0.01^{\mathrm{a}}$ & $1.00 \pm 0.24^{\mathrm{b}}$ & $0.94 \pm 0.16^{\mathrm{b}}$ \\
\hline & $\mathrm{D}$ & $0.75 \pm 0.01^{\mathrm{b}}$ & $0.70 \pm 0.17^{\mathrm{a}}$ & $0.07 \pm 0.02^{\mathrm{a}}$ & $0.46 \pm 0.14^{\mathrm{c}}$ & $1.44 \pm 0.06^{\mathrm{ab}}$ \\
\hline & E & $0.84 \pm 0.03^{\mathrm{ab}}$ & $0.91 \pm 0.00^{\mathrm{a}}$ & $0.08 \pm 0.01^{\mathrm{a}}$ & $0.22 \pm 0.04^{\mathrm{bc}}$ & $2.06 \pm 0.18^{\mathrm{a}}$ \\
\hline
\end{tabular}

Results are expressed as means \pm standard deviation of four cheeses, two for each trial

${ }^{\mathrm{a}-\mathrm{c}}$ Means in each column and at the same sampling date with a common letter did not differ significantly $(p>0.05)$

${ }^{\mathrm{d}}$ Salt treatment: symbols as displayed in Table 1

labelled as "low sodium" food as they contain more than $120 \mathrm{mg}$ Na per $100 \mathrm{~g}$ of food product at 17 days of ripening; hence, they do not fulfill the Corrigendum to Regulation (EC) No. 1924/2006. Nevertheless, experimental São João cheeses with $50 \%$ and $75 \%$ replacement of $\mathrm{NaCl}$ can be labelled as "reduced in sodium" according to the aforementioned Corrigendum to EU Regulation, because they contain at least $25 \%$ less salt than the full-sodium control.

\subsection{Microbiological analysis}

The cheese samples were analyzed for total bacterial count, Enterobacteriaceae, coagulase positive staphylococci, and yeasts and molds at 17 days of ripening. The effect of substitution of $\mathrm{NaCl}$ by $\mathrm{KCl}$ according to ANOVA is displayed in Table 3. Furthermore, analyses for detection of Salmonella spp., L. monocytogenes, and E. coli were conducted. 
a

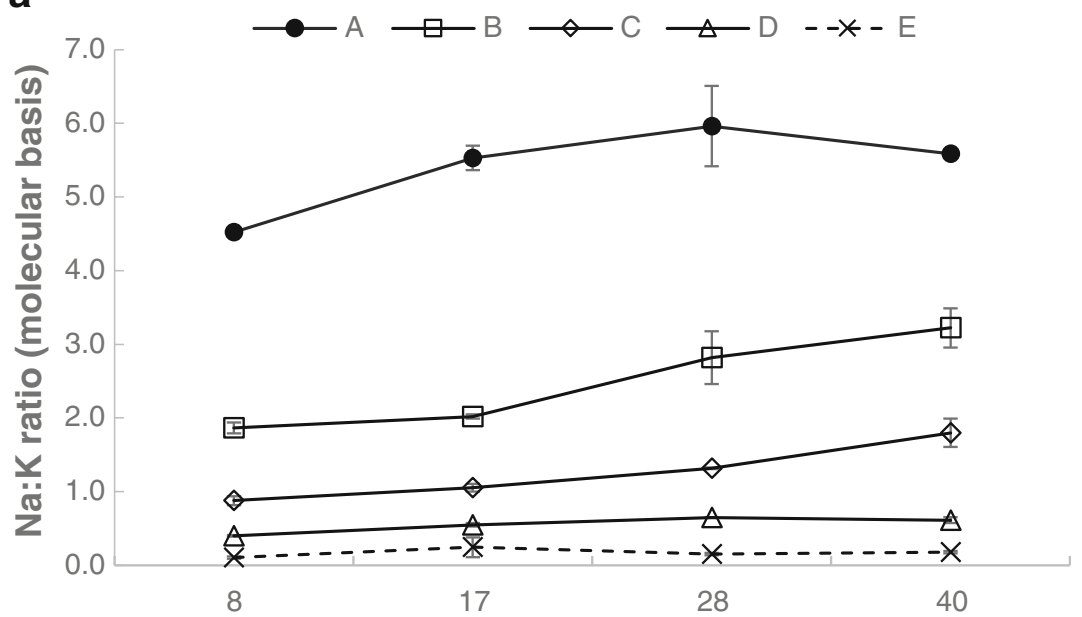

Ripening time (d)

b

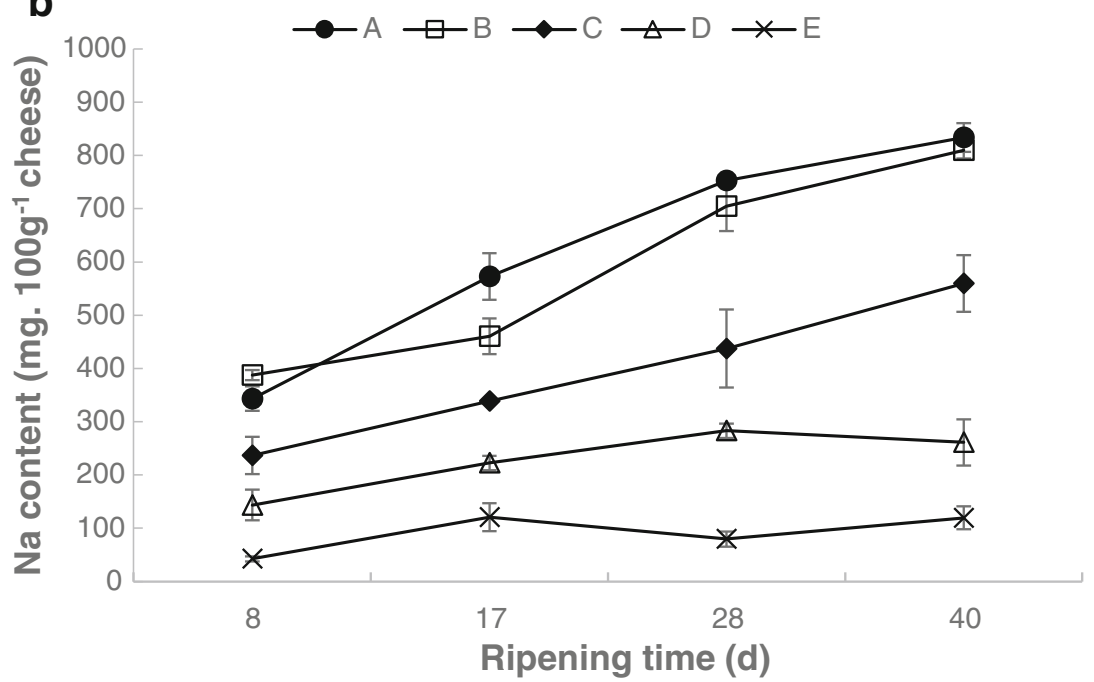

Fig. 2 a Na/K ratio of São João cheeses salted with five levels of $\mathrm{NaCl}(\mathrm{Na} / \mathrm{K}$ ratio was calculated by the following expression: $\mathrm{Na} / \mathrm{K}$ (molecular basis) $=\mathrm{Na} / \mathrm{K}$ (gravimetric basis) $\times(39 / 23)$, as meq Na $=\mathrm{mg} \mathrm{Na} / 23$ and meq $\mathrm{K}=\mathrm{mg} \mathrm{K} / 39$. b Sodium content of São João cheeses salted with five levels of $\mathrm{NaCl}$. In both graphs, a and $\mathbf{b}$, the five salt treatments refer to $A=\mathrm{NaCl}$ only (control), $B=3 \mathrm{NaCl} / 1 \mathrm{KCl}(w / w), C=1 \mathrm{NaCl} / 1 \mathrm{KCl}(w /$ $w), D=1 \mathrm{NaCl} / 3 \mathrm{KCl}(w / w), E=\mathrm{KCl}$ only, during 40 days of ripening

The total aerobic mesophilic counts mostly correspond to the lactic acid bacteria (LAB) added after milk pasteurization. There were no significant effects of salting on the total bacterial count at 17 days, which is in contrast to Aly (1995) who found a significant decrease on the growth of total bacterial count with salt replacement up to $75 \%$ in UF Feta-type cheese.

Enterobacteriaceae counts of the control and experimental cheeses were high. Similarly to the preceding microorganisms, no difference among salting treatments 
Table 3 Microbial counts $\left(\log _{10}\right.$ cfu. $\left.\mathrm{g}^{-1}\right)$ of 17-day-old São João cheese salted with different mixtures of $\mathrm{NaCl}$ and $\mathrm{KCl}$

\begin{tabular}{lllll}
\hline $\begin{array}{l}\text { Salt } \\
\text { treatment }^{\mathrm{c}}\end{array}$ & $\begin{array}{l}\text { Total viable } \\
\text { microorganisms }\end{array}$ & Enterobacteriaceae & $\begin{array}{l}\text { Coagulase positive } \\
\text { staphylococci }\end{array}$ & $\begin{array}{l}\text { Yeasts and } \\
\text { molds }\end{array}$ \\
\hline $\mathrm{A}$ & $7.80 \pm 0.27^{\mathrm{a}}$ & $5.12 \pm 0.35^{\mathrm{a}}$ & $1.96 \pm 0.19^{\mathrm{a}}$ & $2.51 \pm 0.35^{\mathrm{ab}}$ \\
$\mathrm{B}$ & $8.50 \pm 0.48^{\mathrm{a}}$ & $5.63 \pm 0.36^{\mathrm{a}}$ & $<1.0^{\mathrm{b}}$ & $2.56 \pm 0.28^{\mathrm{ab}}$ \\
$\mathrm{C}$ & $8.58 \pm 0.32^{\mathrm{a}}$ & $4.75 \pm 0.02^{\mathrm{a}}$ & $<1.0^{\mathrm{b}}$ & $3.20 \pm 0.00^{\mathrm{a}}$ \\
$\mathrm{D}$ & $7.53 \pm 0.09^{\mathrm{a}}$ & $4.46 \pm 0.15^{\mathrm{a}}$ & $1.56 \pm 0.23^{\mathrm{a}}$ & $2.14 \pm 0.07^{\mathrm{b}}$ \\
$\mathrm{E}$ & $7.35 \pm 0.16^{\mathrm{a}}$ & $4.33 \pm 0.02^{\mathrm{a}}$ & $1.01 \pm 0.27^{\mathrm{a}}$ & $1.35 \pm 0.00^{\mathrm{b}}$ \\
\hline
\end{tabular}

Results are expressed as means \pm standard deviation of four cheeses, two for each trial

${ }^{\mathrm{a}, \mathrm{b}}$ Means with the same letter in the same column did not differ significantly $(p>0.05)$

${ }^{\mathrm{c}}$ Salt treatment: symbols as displayed in Table 1

was found on the counts of this specific microbial group at 17 days, in accordance to the results of Kamleh et al. (2012) for total coliforms in Halloumi cheese salted with $\mathrm{NaCl} / \mathrm{KCl}$ blends. In spite of the fact that lactic acid bacteria can restrict the growth of other microorganisms (Carvalho et al. 2007), the high levels of Enterobacteriaceae in São João cheese can be related to a possible post-pasteurization contamination caused by hygienic flaws in the dairy plant environment, processing equipment, storage facilities, and staff (Kamleh et al. 2012; Kousta et al. 2010).

The coagulase positive staphylococci counts were below the microbiological criteria set by Commission Regulation (EC) No. 1441/2007. There were significant $(p<0.05)$ differences on the growth of this specific category among experimental São João cheeses. However, the effect observed is most likely due to mishandling by the workers, which is one of the main sources of $S$. aureus contamination (Carvalho et al. 2007), and not to salt replacement itself.

In general, all experimental cheeses exhibited substantial yeast and mold counts; however, salting treatments do not seem to encourage the growth of fungal flora, as each one of the reduced-sodium experimental São João cheese was nearly similar $(p>0.05)$ to the control. Besides, cheeses D and E revealed significantly lower yeasts and molds compared to the control, suggesting that cheeses above $75 \%$ replacement with $\mathrm{KCl}$ inhibited the development of the fungal flora. These findings agree with results of Aly (1995) and Kamleh et al. (2012) for UF Feta-type and Halloumi cheeses, respectively.

Despite that, the contamination by Enterobacteriaceae may indicate the presence of enteropathogenic bacteria, neither Salmonella spp. nor E. coli were isolated from any test or control cheeses analyzed. Likewise, L. monocytogenes was totally absent in all tested cheeses.

Therefore, the microbial counts of São João cheeses made with $\mathrm{NaCl} / \mathrm{KCl}$ blends or $\mathrm{KCl}$ only did not differ, similarly to the work of Soares et al. (2015) by lowering salt solely in São João cheese. Hence, the substitution of $\mathrm{NaCl}$ by $\mathrm{KCl}$ does not seem to bring any downside concerning the microbiological quality of São João cheese, pointing, however, some post-pasteurization hygienic flaws which can be overcome through the implementation of better cleaning and disinfection programs along with 
good manufacturing and personnel hygiene practices by food handlers (Kousta et al. 2010).

\subsection{Sensory analysis}

Sensory analysis according to the triangle test methodology was performed at 17 days of ripening, in order to detect perceptible differences between control and each experimental São João cheese. The perceptible difference results are given in Table 4.

The sensory analysis by the triangle test of experimental São João cheeses showed that cheeses salted with $\mathrm{NaCl} / \mathrm{KCl}$ mixtures or with $\mathrm{KCl}$ were similar to the control cheese. São João cheeses salted with $\mathrm{NaCl} / \mathrm{KCl}$ blends or $\mathrm{KCl}$ alone were considered alike to the control sample by the assessors, mainly, in terms of flavor. These findings are in agreement with those found by Katsiari et al. (1997, 1998), and Kamleh et al. (2012) in their studies on the effect of $\mathrm{KCl}$ on Feta, Kefalograviera, and Halloumi cheeses up to $50 \%$ replacement, respectively, and also to Grummer et al. (2012) in their study on mineral salt replacers in Cheddar-style cheese up to $60 \%$ substitution of $\mathrm{NaCl}$ by $\mathrm{KCl}$. However they were in contrast to Aly (1995) who found significantly lower flavor scores in the $3 \mathrm{NaCl} / 1 \mathrm{KCl}$ salt treatment on Feta-type cheese. The results are also in contrast with the findings of Lindsay et al. (1982) who reported that reduced-sodium Cheddar cheese, containing $1.25 \%$ or $1.5 \%$ sodium/potassium chloride $(1: 1)$, revealed lower saltiness and higher bitterness intensities, as well as more off-flavor than the simple low-salt counterparts, seemingly attributable to the added $\mathrm{KCl}$ according to this author. Furthermore, the effect observed in the present study is, again, in contrast to an earlier work of Soares et al. (2015) on the effect of decreasing salt, where it was found that São João experimental cheeses with 50\%, 75\%, and 100\% salt reduction were substantially different from the full-sodium control. Therefore, a simple $25 \% \mathrm{NaCl}$ reduction could easily be feasible as previously found by Soares et al. (2015) and probably easily marketed in terms of consumer liking.

\subsection{Texture profile analysis}

Hardness (the force necessary to attain a given deformation), cohesiveness (the strength of internal bonds making up the body of the product), and adhesiveness (the work necessary to overcome the attractive forces between the surface of a food and surfaces

Table 4 Triangle test performed on São João cheese salted with or without added $\mathrm{NaCl}$ or $\mathrm{KCl}$ either single or as mixtures of $\mathrm{NaCl} / \mathrm{KCl}$, at 17 days of ripening

\begin{tabular}{llll}
\hline Salt treatment $^{\mathrm{a}}$ & No. of assessors & No. of correct responses & Results $^{\mathrm{b}}$ \\
\hline B & 30 & 14 & B = A \\
C & 30 & 13 & C = A \\
D & 30 & 14 & D = A \\
E & 30 & 12 & E = A \\
\hline
\end{tabular}

\footnotetext{
${ }^{\text {a }}$ Salt treatment: symbols as displayed in Table 1

${ }^{\mathrm{b}}$ Perceptible difference results concluded from statistical Table A.1 of BS ISO 4120 (2004) for $\alpha=0.05$
} 
of other materials with which it comes in contact) results of São João cheeses salted with $\mathrm{NaCl}$ only (A), or mixtures of $\mathrm{NaCl} / \mathrm{KCl}(\mathrm{B}, \mathrm{C}, \mathrm{D})$, or with $\mathrm{KCl}(\mathrm{E})$, at 17 days of ripening are presented in Table 5.

Significant $(p<0.05)$ differences were found in hardness and cohesiveness textural parameters among experimental cheeses at 17 days of ripening, while adhesiveness $(p>0.05)$ was not different. São João cheese E salted with $\mathrm{KCl}$ was significantly harder $(p<0.05)$ than the control and cheese salted with $(3: 1) \mathrm{NaCl} / \mathrm{KCl}$ mixtures, suggesting that cheeses salted with $\mathrm{KCl}$ lead to a less calcium displacement and probably to higher phosphorous content due to the lack of solubilization, as it can be seen by the decreased in MNFS and S/M among salt treatments, at 17 days of ripening in Table 1 (Rulikowska et al. 2013). The present findings do not agree with those reported by Katsiari et al. (1997, 1998) and Ayyash et al. (2011), who observed a decreasing trend for the hardness for Feta, Kefalograviera, and Halloumi cheeses, respectively. São João cheeses salted with $\mathrm{NaCl} / \mathrm{KCl}$ mixtures and $\mathrm{KCl}$ revealed significantly $(p<0.05)$ lower cohesiveness than the full-sodium control, similar to Ayyash et al. (2011) for Halloumi cheese but in contrast to Katsiari et al. (1998) who report an almost equal cohesiveness among the several $\mathrm{NaCl} / \mathrm{KCl}$-salted Kefalograviera cheeses. The decrease observed in the present study can be probably attributed to less calcium displacement (Cruz et al. 2011; Rulikowska et al. 2013) promoted not only by increasing the amount of added potassium but also by the proteolysis increase as well (Ayyash et al. 2011). This effect may suggest that $\mathrm{KCl}$ is not as effective as is $\mathrm{NaCl}$ by itself in terms of technology, throughout ripening. On the other hand, the results showed that adhesiveness was not statistically different $(p>0.05)$ among experimental cheeses at 17 days of ripening. In conclusion, hardness increased significantly in São João cheese with $\mathrm{NaCl}$ substitution by $\mathrm{KCl}$ at 17 days of ripening, opposite to cohesiveness.

\section{Conclusions}

São João cheese made with partial to total replacement of $\mathrm{NaCl}$ by $\mathrm{KCl}$ in the dry curd salting step were similar to the full-sodium control regarding chemical composition, mainly in terms of protein, fat, and ash contents. There were significant differences,

Table 5 Texture properties of São João cheeses salted with different mixtures of $\mathrm{NaCl}$ and $\mathrm{KCl}$, at 17 days of ripening

\begin{tabular}{llll}
\hline Salt treatment $^{\mathrm{c}}$ & Hardness $(\mathrm{N})$ & Cohesiveness & Adhesiveness (-N.mm) \\
\hline A & $5.02 \pm 1.54^{\mathrm{b}}$ & $0.67 \pm 0.03^{\mathrm{a}}$ & $4.52 \pm 0.91^{\mathrm{a}}$ \\
$\mathrm{B}$ & $5.72 \pm 0.31^{\mathrm{b}}$ & $0.58 \pm 0.03^{\mathrm{a}}$ & $3.71 \pm 1.69^{\mathrm{a}}$ \\
$\mathrm{C}$ & $7.88 \pm 0.46^{\mathrm{a}}$ & $0.48 \pm 0.00^{\mathrm{b}}$ & $4.46 \pm 0.14^{\mathrm{a}}$ \\
$\mathrm{D}$ & $6.93 \pm 0.14^{\mathrm{ab}}$ & $0.50 \pm 0.01^{\mathrm{ab}}$ & $4.54 \pm 0.24^{\mathrm{a}}$ \\
$\mathrm{E}$ & $8.02 \pm 0.33^{\mathrm{a}}$ & $0.46 \pm 0.01^{\mathrm{ab}}$ & $4.75 \pm 0.26^{\mathrm{a}}$ \\
\hline
\end{tabular}

\footnotetext{
Mean values \pm standard deviation of two cheeses, being $n=5$ for each cheese

${ }^{\mathrm{a}, \mathrm{b}}$ Means in each column with a common letter did not differ significantly $(p>0.05)$

${ }^{\mathrm{c}}$ Salt treatment: symbols as displayed in Table 1
} 
however, in moisture, salt, phosphorous, sodium content, and acidity and $\mathrm{pH}$ levels among salting treatments. Moreover, $\mathrm{Na} / \mathrm{K}$ ratio of São João cheese salted with $(1: 1)$ $\mathrm{NaCl} / \mathrm{KCl}$ mixture was in the range recommended by nutritionists.

The use of potassium chloride does not involve major significant differences in the overall microbiological quality, which was within acceptable limits. Conversely, substitution of $\mathrm{NaCl}$ by $\mathrm{KCl}$ influenced the texture profile of São João cheese, which was significantly harder and significantly less cohesive by increasing the potassium chloride at more than $50 \% \mathrm{KCl}$ in the salting mixture.

Overall, cheeses formulated with $(3: 1)$ or $(1: 1) \mathrm{NaCl} / \mathrm{KCl}$ mixtures were found to be more suitable in terms of industrial production, as the gross composition, microbiological characteristics, and sensory properties were not affected.

Acknowledgments The authors gratefully acknowledge the help of Queijaria do Pico (Dairy of Pico Island) for cheese manufacture.

\section{References}

Alvarenga N, Silva P, Garcia JR, Sousa I (2008) Estimation of Serpa cheese ripening time using multiple linear regression (MLR) considering rheological, physical and chemical data. J Dairy Res 75:233-239

Alvarenga N, Canada J, Sousa I (2011) Effect of freezing on the rheological, chemical and colour properties of Serpa cheese. J Dairy Res 78:80-87

Aly ME (1995) An attempt for producing low-sodium Feta-type cheese. Food Chem 52:295-299

AOAC (1990) Official methods of analysis of the Association of Official Analytical Chemists, 15th edn. Association of Official Analytical Chemists, Washington

Ayyash MM, Shah NP (2010) Effect of partial substitution of $\mathrm{NaCl}$ with $\mathrm{KCl}$ on Halloumi cheese during storage: chemical composition, lactic bacterial count, and organic acids production. J Food Sci 75:525529

Ayyash MM, Sherkat F, Francis P, Williams RPW, Shah NP (2011) The effect of sodium chloride substitution with potassium chloride on texture profile and microstructure of Halloumi cheese. J Dairy Sci 94:37-42

BS (2004) Sensory analysis — methodology — triangle test. The British Standards Institution, United Kingdom, In BS ISO 4120:2004

Carvalho JDG, Viotto WH, Kuaye AY (2007) The quality of Minas Frescal cheese produced by different technological processes. Food Control 18:262-267

Cichoscki AJ, Valduga E, Valduga AT, Tornadijo ME, Fresno JM (2002) Characterization of Prato cheese, a Brazilian semi-hard cow variety: evolution of physico-chemical parameters and mineral composition during ripening. Food Control 13:329-336

Codex (1978) Codex general standard for cheese (Codex Stan 283-1978). Revised 2013. Available from http://www.fao.org/fao-who-codexalimentarius/en/ [Acessed 10 May 2016].

Commission Regulation (EC) No. 1441/2007 of 5 December 2007, amending Regulation (EC) No. 2073/2005 on microbiological criteria for foodstuffs. In Official Journal of the European Union, L 322 of 7 December 2007.

Cook NR, Cutler JA, Obarzanek E, Buring JE, Rexrode KM, Kumanyika SK, Appel LJ, Whelton PK (2007) Long term effects of dietary sodium reduction on cardiovascular disease outcomes: observational followup of the trials of hypertension prevention (TOHP). BMJ 334(7599):885-888

Cruz AG, Faria JAF, Pollonio MAR, Bolini HMA, Celeghini RMS, Granato D, Shah NP (2011) Review: cheeses with reduced sodium content: effects on functionality, public health benefits and sensory properties. Trends Food Sci Technol 22:276-291

Demott BJ, Hitchcock JJ, Sanders OG (1984) Sodium concentration of selected dairy products and acceptability of a sodium substitute in cottage cheese. J Dairy Sci 67:1539-1543

Despacho Normativo (Legislative Order) No. 32 of 29 October 1996, which establishes the main features of Pico cheese. 
Drake SL, Lopetcharat K, Drake MA (2011) Salty taste in dairy foods: can we reduce the salt? J Dairy Sci 94 : 636-645

Grummer J, Karalus M, Zhang K, Vickers Z, Schoenfuss TC (2012) Manufacture of reduced-sodium cheddarstyle with mineral salt replacers. J Dairy Sci 95:2830-2839

Guinee TP, Fox PF (2004) Salt in cheese: physical, chemical and biological aspects. In: Fox PF (ed) Cheese: chemistry, physics and microbiology, vol 1, 3rd edn. Chapman \& Ha, London, pp 207-259

IDF (2006) Cheese and processed cheese products. Determination of chloride content. Potentiometric titration method. International Dairy Federation, Brussels, In IDF Standard 88

IDF (2007) Milk and milk products. Determination of calcium, sodium, potassium and magnesium contents. Atomic absorption spectrometric method. International Dairy Federation, Brussels, In IDF Standard 119

IDF (2008a) Milk and milk products, Guidance on sampling. International Dairy Federation, Brussels, In IDF Standard 50

IDF (2008b) Processed cheese products. Determination of nitrogen content and crude protein calculation. Kjeldahl method. International Dairy Federation, Brussels, In IDF Standard 25

IDF (2010) Cheese and processed cheese products. Determination of total phosphorous content. Molecular absorption spectrometric method. International Dairy Federation, Brussels, In IDF Standard 33

ISO (1998) Microbiology of food and animal feeding stuffs. Horizontal method for the detection and enumeration of Listeria monocytogenes. Part 2: enumeration method. International Organisation for Standardisation, Delft, In ISO standard 11290-2:1998/Amd. 1:2004

ISO (1999) Microbiology of food and animal feeding stuffs. Preparation of test samples, initial suspension and decimal dilutions for microbiological examination. Part 1. General rules for the preparation of the initial suspension and decimal solutions. International Organisation for Standardisation, Delft, In ISO standard 6887-1:1999

ISO (2002) Microbiology of food and animal feeding stuffs - horizontal method for the detection of Salmonella spp. International Organisation for Standardisation, Delft, In ISO standard 6579:2002

ISO (2005) Microbiology of food and animal feeding stuffs. Horizontal method for the detection and enumeration of presumptive Escherichia coli. Most probable number technique. International Organisation for Standardisation, Delft, In ISO standard 7251:2005

Kamleh R, Olabi A, Toufeili I, Najm NEO, Younis T, Ajib R (2012) The effect of substitution of sodium chloride with potassium chloride on the physicochemical, microbiological, and sensory properties of Halloumi cheese. J Dairy Sci 95:1140-1151

Kaplan NM (2000) The dietary guideline for sodium: should we shake it up? Am J Clin Nutr 71(5):1020-1026

Karahadian C, Lindsay RC (1984) Flavour and textural properties of reduced-sodium process American cheeses. J Dairy Sci 67:1892-1904

Katsiari MC, Voutsinas LP, Alichanidis E, Roussis IG (1997) Reduction of sodium content in feta cheese by partial substitution of $\mathrm{NaCl}$ by $\mathrm{KCl}$. Int Dairy J 7:465-472

Katsiari MC, Voutsinas LP, Alichanidis E, Roussis IG (1998) Manufacture of Kefalograviera cheese with less sodium by partial replacement of $\mathrm{NaCl}$ with $\mathrm{KCl}$. Food Chem 61:63-70

Kousta M, Mataragas M, Skandamis P, Drosinos EH (2010) Review: prevalence and sources of cheese contamination with pathogens at farm and processing levels. Food Control 21:805-815

Lindsay RC, Hargett SM, Bush CS (1982) Effect of sodium/potassium (1:1) chloride and low sodium chloride concentrations on quality of Cheddar cheese. J Dairy Sci 65:360-370

Massey LK (2005) Effect of dietary salt intake on circadian calcium metabolism, bone turnover, and calcium oxalate kidney stone risk in postmenopausal women. Nutr Res 25:891-903

McMahon DJ, Oberg CJ, Drake MA, Farkye N, Moyes LV, Arnold MR, Ganesan B, Steele J, Broadbent JR (2014) Effect of sodium, potassium, magnesium, and calcium salt cations on $\mathrm{pH}$, proteolysis, organic acids, and microbial populations during storage of full-fat Cheddar cheese. J Dairy Sci 97:4780-4798

Corrigendum to Regulation (EC) No 1924/2006 of the European Parliament and of the Council of 20 December 2006 on nutrition and health claims made on foods. In Official Journal of the European Union, L 12 on 18th January 2007.

NP (1998) Cheese and processed cheese. Determination of the lactose content. Directorate-General of Quality, Portuguese Institute for Quality, Caparica, In NP Portuguese Standard 2104:1998

Reps A, Wisniewska K, Kuzmicka M (2009) Possibilities of increasing the potassium content of processed cheese spread. Milchwissenschaft 64(2):176-179

Rulikowska A, Kilcawley KN, Doolan IA, Alonso-Gomez M, Nongonierma AB, Hannon JA, Wilkinson MG (2013) The impact of reduced sodium chloride content on Cheddar cheese quality. Int Dairy J 28:45-55

Soares C, Fernando AL, Mendes B, Martins APL (2015) The effect of lowering salt on the physicochemical, microbiological and sensory properties of São João cheese of Pico Island. Int J Dairy Technol 67:1-11

Wyatt CJ (1983) Acceptability of reduced sodium in breads, cottage cheese, and pickles. J Food Sci 48:1300-1302

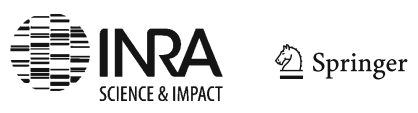

